\title{
The Daintree Canopy Crane: Conception, Installation and Operation
}

\author{
Nigel E. Stork ${ }^{1}$
}

\begin{abstract}
The forest canopy is where the biosphere meets the atmosphere, and yet it has been poorly understood due to its inaccessibility. In the early 1990s, interest in the canopy of forests was increasing and researchers sought to attain greater access through the use of industrial cranes. In 1998 a crane was lowered, section by section, by helicopter and constructed in an area of lowland rainforest in the Daintree area of North Queensland. The constructed crane is $47 \mathrm{~m}$ high with a $55 \mathrm{~m}$ length jib providing access to the canopy of forest covering almost a hectare and including roughly 680 tree stems $>10 \mathrm{~cm}$ DBH of 82 species. Since its installation, the crane has been used to provide novel insights into a range of fields including plant ecology and physiology, forest microclimate, and faunal and floral diversity. There has been a strong focus on insects including pollination and ant ecology, vertical distribution of insects from the ground to upper canopy, and the hidden diversity of insects and flowers. Current research using the crane is largely focused on the impacts of experimentally induced drought on trees and saplings and the consequences for insects. This paper describes the installation of the crane and initial management and functioning of the research facility. It provides insights on how best to install a canopy crane and maximise its use, as well as the pitfalls to avoid. Also addressed are the potential experimental problems posed by having a single site facility.
\end{abstract}

Keywords: last biotic frontier, forest canopy, tropical rainforest, canopy access, forest drought experiment

${ }^{1}$ Centre for Planetary Health and Food Security, Griffith School of Environment and Science, Griffith University, Nathan 4111, Australia (nigel.stork@griffith.edu.au)

Stork, N. E. (2021). The Daintree Canopy Crane: Conception, installation and operation. Proceedings of The Royal Society of Queensland, 129, 79-90. https://doi.org/10.53060/prsq. 2021.6

\section{Introduction}

The first so-called 'canopy crane' was inspired by Smithsonian Tropical Research Institute (STRI) scientist Alan Smith who, when passing through Miami Airport to Panama from the USA, saw all the construction cranes and realised that these might be a novel way of accessing the tops of trees for researchers. With funding from UNEP, this led to the first canopy crane being installed in the Parque Natural Metropolitano on the outskirts of Panama City in 1990 (Parker et al., 1992).

Forests house a large proportion of Earth's terrestrial biomass, and the forest canopy is the functional interface with the atmosphere (Ozanne et al., 2003). I was interested in the question of how many species of insects there were in the world and what proportion were only found in the rainforest canopy (Erwin, 1982; Stork, 2018; Stork \& Grimbacher, 2006) but had previously collected samples of insects from the tops of trees using knockdown insecticides released from a fogging machine hauled up into the canopy (Stork, 1991). Other canopy scientists had been using single rope techniques to haul themselves into the tops of trees, but safe access to the outer canopy had been difficult or impossible. The beauty of the canopy crane is

This work is licensed under a Creative Commons Attribution-NonCommercial-NoDerivatives 4.0 International Licence. Individual articles may be copied or downloaded for private, scholarly and not-for-profit use. Quotations may be extracted provided that the author and The Royal Society of Queensland are acknowledged. Queries regarding republication of papers, or parts of papers such as figures and photographs, should be addressed to the Secretary of The Royal Society of Queensland (rsocqld@gmail.com). 
that the researcher(s) could be lifted into the canopy in a traditional 'dog-box', now called a gondola by canopy scientists, and could take up equipment and sample directly from leaves and branches with ease. Over a 10-year period from the establishment of the first STRI crane, more than 10 other canopy cranes were established for different research purposes in forests around the world (Basset et al., 2003; Stork et al., 1997). Currently, there are six canopy cranes in China alone (Nakamura et al., 2017).

I visited STRI shortly after their crane had been installed and saw the immense possibilities for different kinds of research that the crane provided. In October 1995, I moved to Australia from the Natural History Museum in London to take up the position as CEO of the Cooperative Research Centre for Tropical Rainforest Ecology and Management (Rainforest CRC) and Professor at the new Cairns James Cook University campus. In the first few months, I explored the possibility of seeking Australian Research Council funding to fund the purchase and installation of a canopy crane. The idea was enthusiastically supported by JCU's Professor Peter Arlett (Deputy Vice Chancellor Research) and Professor Rhondda Jones (Head of Department of Zoology) and by their equivalents at The University of Queensland (UQ) and Griffith University (GU). Most importantly, it was supported by former Chief Scientist, Professor Ralph Slatyer, who was Chair of the Rainforest CRC, as well as other Board Directors of the CRC.

In April 1996, JCU submitted the proposal I'd written to the ARC Large Infrastructure grant scheme. As is usual in such large research infrastructure, the ARC likes to see that it is shared and used by other universities, and UQ and GU partnered JCU for this submission. The proposal outlined why a canopy crane was a much-needed device to support terrestrial research and argued that just as marine scientists used deep-sea submersibles to access the deep waters of oceans, canopy scientists needed cranes to provide safe and repeatable access to the tops of trees. In the proposal, several researchers, including myself, Professor Craig Moritz (UQ) and Professor Roger Kitching (GU), outlined how, if it were funded, we would use the crane for a range of studies, including plant biology, genetics, ecology and entomology.

In November 1996, the ARC announced that it had awarded $\$ 800,000$ to the consortium for the canopy crane - the largest large infrastructure grant awarded that year. In addition, JCU, UQ and GU had put up $\$ 200,000, \$ 100,000$ and $\$ 80,000$ matching funds, respectively, giving a total of $\$ 1,180,000$.

\section{Crane Site Assessment, Building Approvals, and Installation}

There were four main hurdles to overcome: first, to select a site to locate the crane; second, to decide what crane to buy; third, to get the necessary planning permits to erect it; and fourth, to erect the crane in the forest with minimal impact on the surrounding forest. In early 1997, Fiona Barron was appointed as the project officer to manage the crane project. Fiona had recently completed an Honours degree working in the Daintree, was familiar with the local people and local issues, and was well equipped to do most of the planning work and discussions with contractors.

By the time the grant was awarded, there were several canopy cranes in action, including one in Washington State in the USA and one in Venezuela which was funded through the Austrian Academy of Science. These, in addition to the original Panama crane, were all tower cranes. This type of crane has advantages over other types, as the arm of the crane stands above the forest and provides access to a large area underneath the arc of the arm. Other cranes would still need to be fixed to a tower above the forest but would not be so easy to use for accessing the forest. At that time there were only a couple of tower cranes operating in Australia, and we approached Morrow, a company specialising in crane hire, purchase and maintenance based in Sydney. The Daintree location meant that the crane would need to withstand high humidity, potentially some salt erosion as it would be located not far from the coast, and most important of all, the ability to withstand cyclonic weather. At that time there were a lot of second-hand cranes in Asia and we could have purchased one of these and saved a lot of money, but we planned for the crane to be standing for many years in harsh conditions and did not take up this option. Morrow's agent, Bill Jones, recommended that we buy a Liebherr Tower crane, noting that in the previous year one such crane had withstood a cyclone in Guam. We were also 
aware that the Venezuelan crane was a Liebherr crane, and through discussions with Professor Wilfried Morawetz, who was the leader of the Austrian-funded project, we were familiar with its construction and installation. Through Morrow we purchased a Liebherr 70 EC Tower crane built in Germany. The crane comprises some 40 parts, and all the metal standing components were treated to ensure longevity before being shipped to Australia.

Where to site the crane was a critical issue. One possibility was in the forest directly behind the new JCU Cairns campus in Smithfield, but this forest had been logged more than once, as had so much of the lowland forest in Far North Queensland. We were seeking an area that had been lightly impacted and preferably not logged. To explore the best option, we sought the advice of Peter Hitchcock, then CEO of the Wet Tropics Management Authority and responsible to Federal and State governments for the safe management of the World Heritage area. Another site considered was in the rainforest at Davies Creek in the Atherton Tablelands where University of California, Santa Barbara, researcher, Professor Joe Connell, had worked for many decades; access to the site was the problem here, especially for the trucks bringing in the crane parts. Peter Hitchcock and I considered that a location in the Daintree would be the best option, as modelling by Professor Henry Nix (ANU) indicated that during recent ice ages, rainforests of the Wet Tropics had contracted down to just a few areas, with the small coastal area north of the Daintree River being one of the main refuges (Nix, 1991). We visited the Daintree. Peter knew the area exceptionally well because of the buy-back program where privately owned areas of exceptional world heritage value were being purchased and incorporated into the World Heritage area. We looked at a number of sites, and one that stood out as relatively pristine was in the forest behind Coconut Beach Resort near Cape Tribulation. This was our favoured choice.

In mid-November 1996, we were informed that our grant application had been successful. In our press release, which was covered nationally, we included a short video clip with an animation of what the crane would look like in action. As a result of this coverage, I was approached by Darryl Bresnahan, a Cairns businessman and owner of Coconut Beach Resort, who had seen the news. We then commenced negotiations to locate the crane in forest on land behind the resort. These negotiations were delayed for more than six months, as a consortium had an option to purchase the resort and associated land. Once that option expired, Darryl agreed to lease an area of forest and land in front of the forest for a peppercorn rent. The agreement also allowed us access to the site using an unused track which led to Cape Tribulation Road.

Planning permission from Douglas Shire Council was required to install the crane, and we hired the services of a local planner to prepare a proposal. One of the criteria we needed to satisfy council was that the crane would not be obvious from the road and from out at sea. To do this a large, coloured balloon was tethered $50 \mathrm{~m}$ from the ground where the crane was to be located, and we then had photographs taken to show that it was not visible from either the road to Cape Tribulation or from the sea. Further, we had the crane painted matt black as this would mean that it would be less visible against the forest backdrop. Plans were submitted, and Douglas Shire Council approved planning permission in 1997. The area for the crane did not fall in nor have a boundary with the Daintree National Park, part of the Wet Tropics World Heritage Area, and hence we did not have to meet any particular requirements. Nonetheless, we briefed both WTMA and Queensland Parks and Wildlife Service of our plans and kept them informed.

Identifying the precise site for the crane to be located and the new track to it from the edge of the forest took some careful thought. We needed to be careful to make sure that the crane tower was tall enough to allow the arm and suspended gondola free movement above the canopy, but not too tall since moving the gondola from one place to another required raising it close to the jib, moving the jib round and then lowering into the canopy - failure to do this would result in the gondola swinging around. We used a clinometer to calculate the height of the tallest trees. Standing 15-20 m from the base of a tree, the clinometer measures the angle needed to sight the top of the tree. In essence, the estimated height of the tree is based on that angle and the distance from the base of the tree where you are standing. We chose a reasonably level area and 
avoided the east of the site where the ground rose sharply. The base of the crane required a clear area roughly $7 \mathrm{~m} \times 7 \mathrm{~m}$, and no large trees were removed (Figure 1a). The proposed $2 \mathrm{~m}$ wide track was flagged on the ground, and the highly experienced local field botanist, Andrew Small, was employed to check that no endangered species of plants were inside the crane base area or the proposed track. Although no heavy machinery was to be used in the forest, the track was covered with a fabric that spread the load and then covered with gravel as proposed by Guy Chester of GHD. A culvert was created to allow a very large matchbox vine to continue to pass under the track. In the clearing for the crane tower, four concrete pads were made - one for each corner of the base of the tower - and each had large bolts protruding (see https://nqheritage. jcu.edu.au/849/ for additional photographs of the installation of the crane).

One of the Directors of the Rainforest CRC, Dr Ken Chapman, Managing Director of Skyrail, shared his considerable experience of how to install large infrastructures in rainforest with minimal damage to the environment. He had the towers for Skyrail installed by lowering them into place using powerful helicopters. He advised that there were only a few helicopter pilots in the world who had the skill to carry out these kinds of operations. His words of advice resonated when I saw footage of the Austrian team trying to lower crane sections into place at the Venezuelan site using the Venezuelan air force helicopter pilots. The crane sections were swinging around wildly, and they had to abandon their attempt and wait six months until they could get a team of industrial pilots to perform the operation safely.

Consequently, we employed the services of Hevilift, who had lowered Skyrail's towers into place. For this kind of operation Hevilift uses a Kamov Russian-made helicopter which has two counter-rotating blades and can lift 5 tonnes in a single lift. The helicopter has two pilots and several other crew to manage the lifting. Inside the helicopter the instructions are in Russian, so at least one of the team needed to be able to read Russian. Finding the right time in late 1998 to carry out the installation was difficult as the helicopter was in heavy demand assisting mining operations in PNG, as well as helping with water bombing in south-east
Australia during fire season. We were particularly concerned that the crane be installed before the onset of the wet season, and Hevilift agreed to a date of 18 November. To do this we had to pay for the costs of the helicopter flying up from Sydney and for three days' use. This amounted to a quarter of our budget.

The crane parts were loaded on a convoy of transporters and brought up from Sydney. To get to the site they had to negotiate their way through the very windy Cape Tribulation Road, many parts of which were still unsealed, and cross the renowned Noah Creek wooden bridge. They were then unloaded and laid out on an open area of land near the staff quarters of Coconut Beach Resort (Figure 1b). We were praying for good weather and no wind, as any delays in the construction would add to our costs for helicopter time. Bill Morrow had some months earlier suggested that the large concrete blocks that fit into a frame at the stabilising end of the jib needed to be very exact in their measurements. If one or more didn't fit in the cradle, this would result in immense delays and additional costs. We had intended the blocks to be made locally but agreed that they should be made in Sydney and shipped up with the other equipment (Figure 1d).

On the morning of 16 November, the scene was set for an extraordinary construction feat. The Kamov helicopter and crew were ready on the grass launching pad at Coconut Beach resort, as was a second smaller helicopter Hevilift had brought in to film the whole operation. Laid out in front of the Kamov were all the crane parts. Next to the Kamov were some 30 drums of aviation fuel which the helicopter would go through over the next few days. As the Kamov rose up it lowered a $100 \mathrm{~m}$ cable, and the first piece, the base of the tower, was attached and lifted into the air (Figure 1c) (see https://nqheritage.jcu.edu.au/850/ for video of the helicopter installing the canopy crane). The longer the cable the more difficult it is to control the swing of the object being carried, but a shorter cable would result in considerable damage to the forest because of the immense downdraft from the rotating blades; hence the $100 \mathrm{~m}$ cable length. At the crane site a team of experienced riggers, led by Craig Jones, Bill's son, and colleagues were attaching the crane pieces as they were lowered. Once the tower base 
was lowered and bolted in place, the next pieces to be individually lifted and placed were the 16 concrete ballast slabs on the four sides of the tower base. Gradually, the crane tower was built up and bolted in place (Figure 1e). Much of the construction was captured on film by the small helicopter, including some exciting footage of the platform and jib sections being lowered gently down and bolted into place. There was some strong wind damage to the forest on one side of the crane site where the Kamov had repeatedly made its approach; however, much of this damage looked like leaf fall, and we considered that this would recover in a matter of months. The constructed crane is $47 \mathrm{~m}$ in height with a jib length of $55 \mathrm{~m}$, and hence the arc of the crane covers an area of 0.95 hectares.
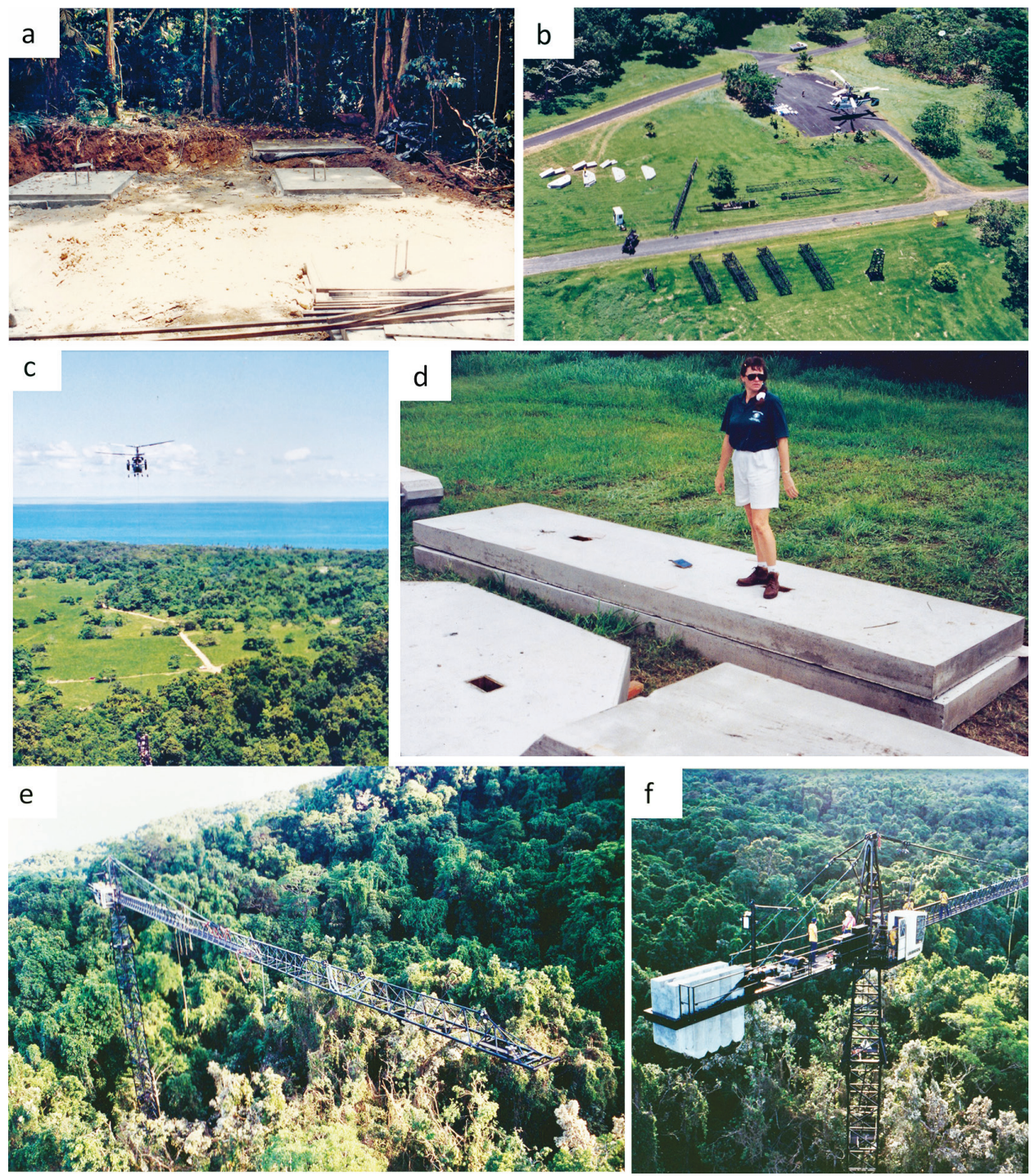

FIGURE 1. (a) Initial concrete slabs set in the ground as the base for the crane; (b) all of the crane parts laid on the ground with the helicopter located close by to make the lifts; (c) the helicopter carefully lowering a section of the jib; (d) Fiona Barron inspecting the concrete ballast and base section weights; (e-f) all sections of the crane attached by the rigging team, including ballast weights. 
With the crane erected, the next job was to fence the area around its base and to install power to it. Power was provided by a large diesel-fuelled generator which was located in a purpose-built shed set outside the forest, along with a fuel tank. A power cable sheathed in a metal pipe was passed through the forest to a control panel with safety switches in a small shed in the fenced area. A gondola had been constructed according to the design suggested by Morrow, but it was found to be too heavy and could not be taken out to the end of the jib without setting off an alarm. A new, lighter gondola was constructed which would accommodate three people. The driver could control the crane from the gondola using a control system attached to his waist (Figure 2b).

\section{Developing a Research Program}

Establishment of a research program at the crane took several years and was impacted by delays caused by damage to the site and facilities by Cyclone Rona, a category 3 cyclone that hit the site on 11 February 1999 - the eye of the storm passing over Port Douglas some $50 \mathrm{~km}$ south. The canopy crane came through unscathed, but the forest was heavily impacted. A couple of medium-sized trees fell across the base of the crane, demolishing the shed and flattening some of the fencing (Figure 2c). The five-minute walk to the crane from the edge of the forest now was a 30 - to 40 -minute walk as the winds had brought many large trees to the ground. In addition, many of the vines, including all the lawyer cane vines, were brought down, making it hazardous to get through. Most of the trees survived on the site, but a lot had the top branches snapped off and very few leaves were left intact.

The area under the arc of the crane was surveyed, and the positions of all the trees of $>10 \mathrm{~cm}$ diameter at breast height $(\mathrm{DBH})$ were tagged, plotted and identified in 2000 and subsequently again in 2005 (Laidlaw et al., 2007). The 2005 survey found there were 680 stems of $>10 \mathrm{~cm} \mathrm{DBH}$ and 82 tree species. At first, it was difficult to identify individual trees when up in the canopy without lowering the gondola to the ground and looking at the tags on the trees. To overcome this problem a map was created showing the positions of the trees, their DBH and their maximum height in the canopy (Figure 2e). A copy of the map was attached to the ceiling of the gondola, and it was easy then to refer to the tree list to find particular trees of interest. In addition, a steel ring was added to the tower below the jib showing points of the compass. Increasing $10 \mathrm{~m}$ distances from the tower were marked on the jib, and this made it easier to determine where you were on the plot (Figure $2 \mathrm{f}$ ). In practice, the canopy crane drivers became very familiar with many of the individual trees that were commonly used for research and could navigate to these quickly.

Prior to installation of the crane, Fiona, accompanied by Professor Roger Kitching, visited the Wind River crane in Washington State. This was managed by the University of Washington, and they had developed a safety manual and safety procedures. Fiona brought this back and we adapted it for the Daintree crane, adhering to the Queensland Workplace Health and Safety guidelines for tower cranes. Harnesses were worn in the gondola as well as safety hats, although the need for a safety hat was removed later since the gondola had a hard roof. Safety hats were to be worn under the arc of the crane at ground level if the crane was in operation. All newcomers to the site were given a safety briefing, signed to say they understood the regulations, and checked in and out when they entered and left the site. Only a certified crane driver could operate the crane.

For the first two years of operation, accommodation for the crane driver and researchers was rented from the staff area of Coconut Beach resort. This was not sustainable and also meant the crane site was not always secure. A field station for 8-19 people was constructed using four portable cabins at a cost of around $\$ 220,000$ (Figure 3b). One was a two-bedroom unit that was established for the crane driver. The other three were placed together under a curved roof and had a wooden connecting deck (Figure 3d). One of the units was in two parts: the kitchen and a laboratory (Figure 3c). One of the other units comprised an office and two bedrooms which shared a bathroom. The third unit was four bedrooms, again with paired bedrooms sharing bathrooms. A large battery bank was placed in the generator shed and was charged either by the main generator when the crane was idling or from an additional smaller generator. This provided sufficient power to run lighting, washing machine, and air conditioning units for the office, laboratory 
and bedrooms. Large water tanks collected and stored water from the roof of the buildings. Waste went to an underground septic tank. In 2014 the research station was redeveloped and expanded as the Daintree Rainforest Observatory through a Commonwealth grant.
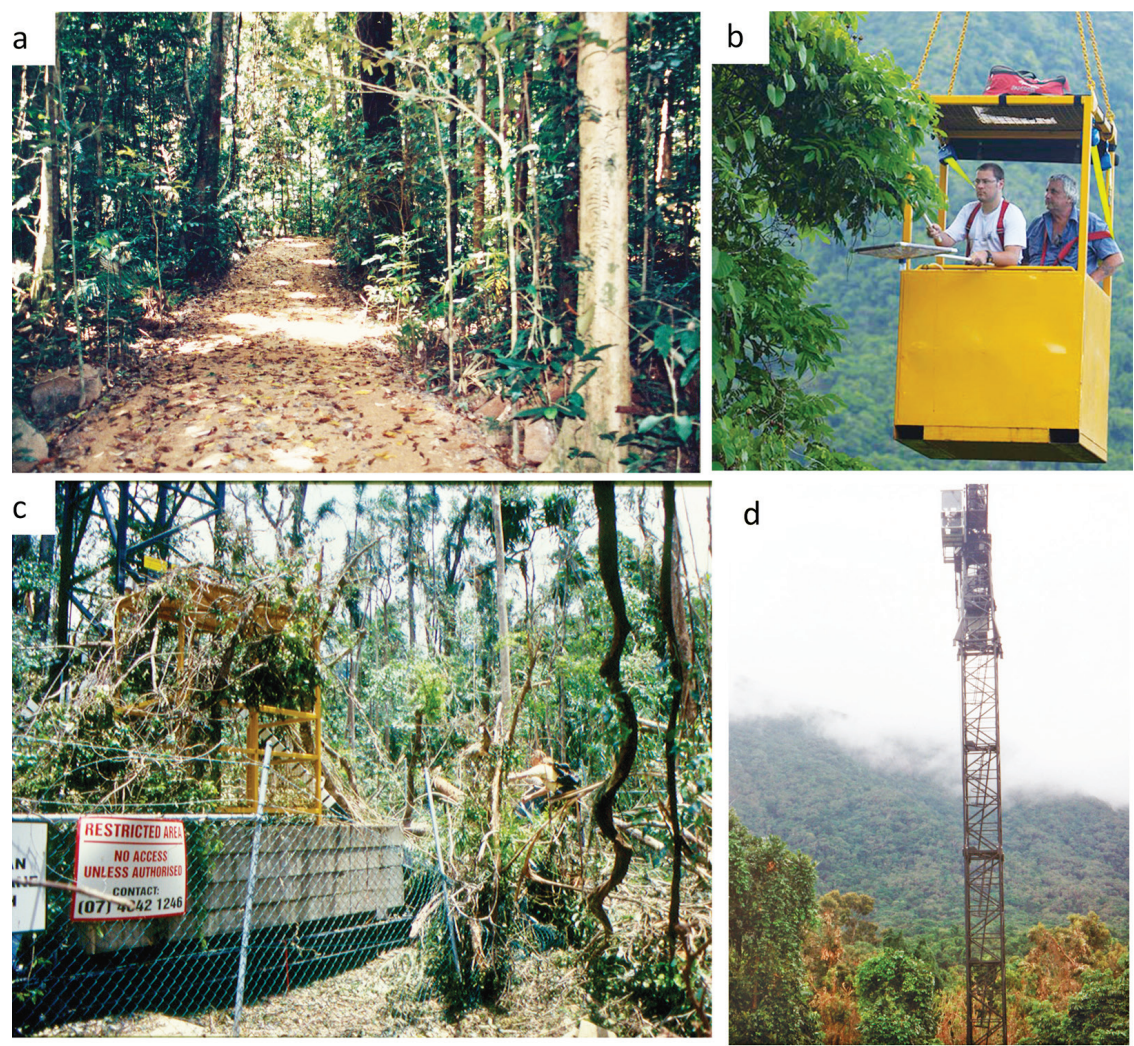

e
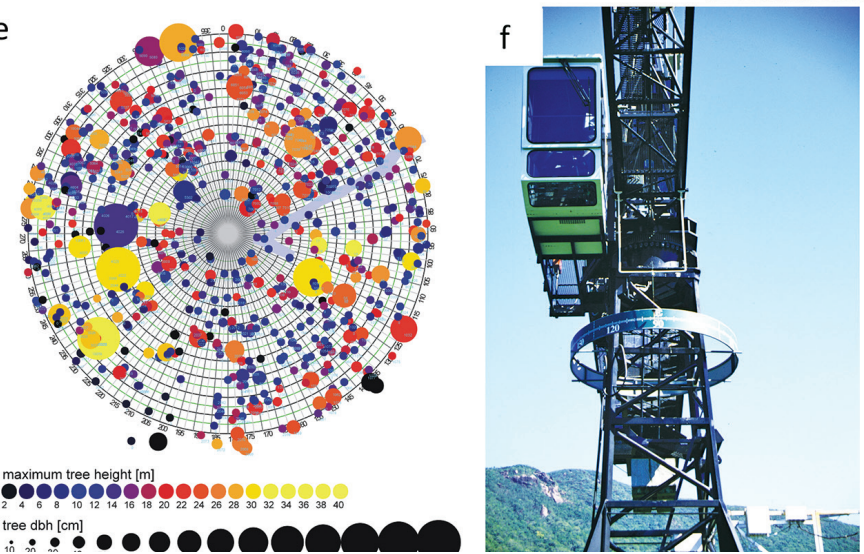

FIGURE 2. (a) Track to the base of the canopy crane; (b) modified gondola showing Dr Carl Wardhaugh collecting insects using a beating tray, with the crane driver using the remotecontrol unit to operate the crane; (c) the damage caused by Cyclone Rona at the base of the crane; (d) the crane tower; (e) map of the crane site showing the numbered trees, their DBH and height; (f) the metal compass band on the crane tower. 

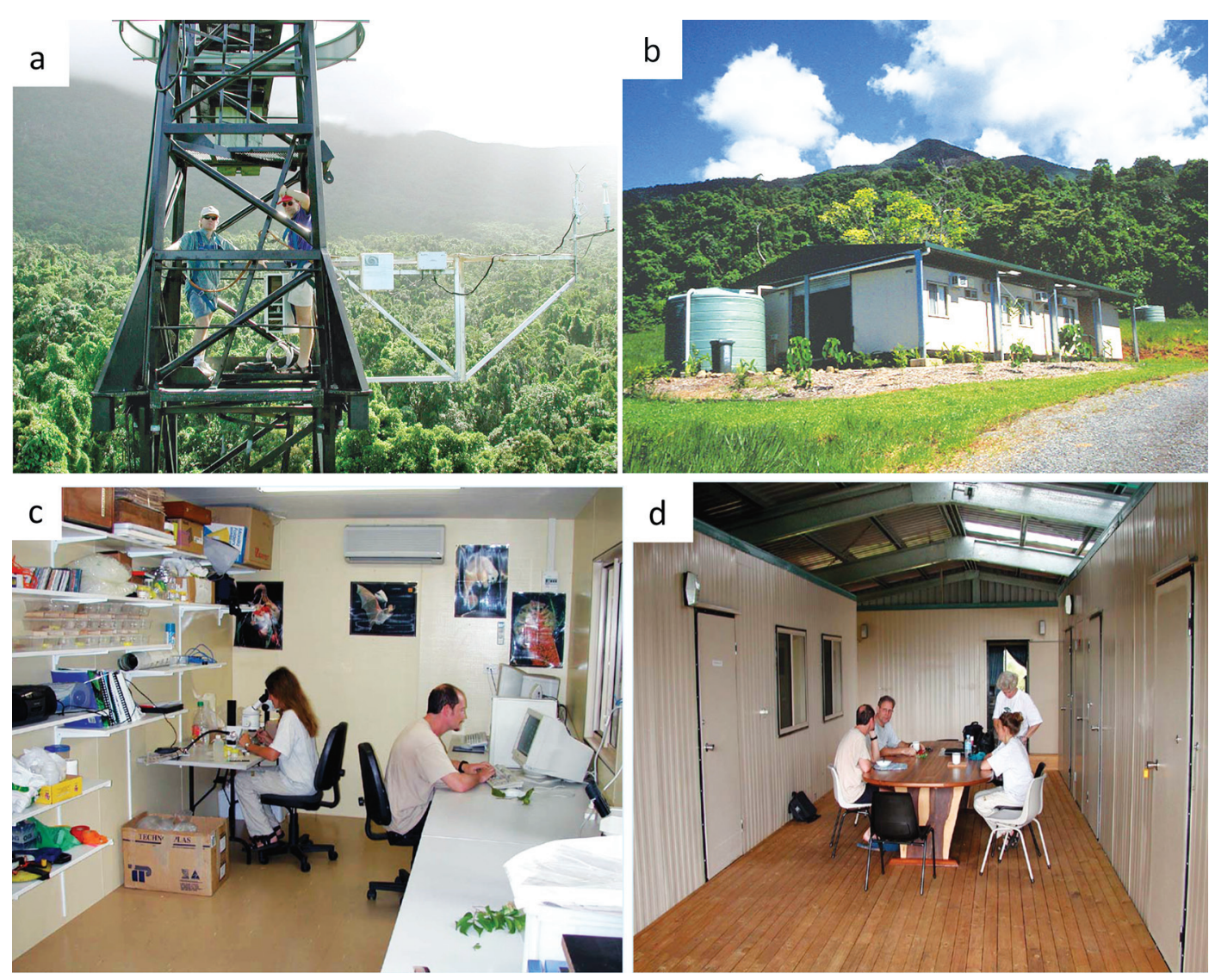

FIGURE 3. (a) Professors Steve Turton and Michael Liddell and the carbon flux apparatus; (b) canopy crane field station; (c) laboratory; (d) community area.

An incorporated company, the Australian Canopy Crane Company, was established to manage the canopy crane. The three universities each had a Director, with the JCU Director, by that time Professor Norman Palmer, also the Chair. NES was the CEO and Ms Carole Peacock, the CRC Business Manager, was the Secretary. Over the next 10 years both UQ and GU resigned their positions on the company, and the facility became wholly owned by JCU. Driving the crane continued to be only by certified tower crane operators, and while several research staff were trained and became certified, there has always been a non-research crane operator on staff to operate the crane.

The Daintree Rainforest Observatory is a Terrestrial Ecosystem Network (TERN) Supersite, and its utility for research has been enhanced by the addition of key infrastructure. This includes weather stations both on the crane tower and outside the forest, a carbon dioxide and water flux station (OzFlux eddy flux covariance) (Figure 3a), sensors measuring soil water content, soil water potential and soil temperature, dendrometer bands on tree trunks, and sap flow sensors.

\section{Research at the Canopy Crane}

In recent years there has been increasing call for whole-ecosystem landscape approaches to experimental manipulations including those targeting weather and climate, nutrients, biotic interactions, human impacts and habitat restoration (Fayle et al., 2015). For tropical forests it could be argued that canopy cranes are an essential tool to study wholeecosystems, for without access to the canopy how can one understand the ecosystem? A number of canopy cranes have been used for single 
experiments, such as those examining forest level responses to increases in $\mathrm{CO}_{2}$ or $\mathrm{O}_{3}$ (Basset et al., 2003), while others have been used for a more diverse range of projects. The Australian crane has been used for a very wide range of studies across many fields of research. Early research focused on forest and epiphyte microclimate (Freiberg \& Turton, 2007; Turton \& Siegenthaler, 2004), ground truthing remote sensing data (Lucas et al., 2004), height strategies of dicot trees (Falster \& Westoby, 2005) and leaf level plant physiology (Franks \& Brodribb, 2005; Franks, 2004). More recent studies have included many aspects of plant ecology such as liana ecology (Buckton et al., 2019; Cox et al., 2019). There has been a strong and continuous effort on insect ecology. Blüthgen and colleagues used stable isotope analysis to look at the feeding ecology of ants in the canopy, showing the importance of sap from Hemiptera and extra-floral nectaries for some largely herbivorous ant species (Blüthgen \& Fiedler, 2002; Blüthgen \& Fiedler, 2004; Blüthgen et al., 2004). There have been surprisingly few detailed long-term studies analysing patterns of diversity in the canopy around the world, but the Australian crane has been used for several. Wardhaugh, as part of his $\mathrm{PhD}$, looked at how insects in the canopy were distributed with respect to different food resources and showed that flowers supported invertebrate densities that are up to ten thousand times greater than on nearby foliage when expressed on a per-unit resource biomass basis (Wardhaugh, Edwards et al., 2013; Wardhaugh et al., 2015; Wardhaugh, Stork, \& Edwards, 2012; Wardhaugh, Stork et al., 2013; Wardhaugh, Stork, Edwards et al., 2012). After sampling 1473 beetle species from canopy and ground traps over four years, a key question for global species estimates was resolved, with similar proportions of species being indicators of ground or canopy and with undescribed species being equally likely to be found in either stratum (Stork \& Grimbacher, 2006; Stork et al., 2008). Other important insect papers have included those on pollination (Boulter et al., 2006; Boulter et al., 2005), host specificity of fruit-eating beetles (Grimbacher et al., 2014), and vertical stratification of insects in the canopy (McCaig et al., 2020; Stork et al., 2016).

With climate change now being acknowledged as one of the greatest threats to biodiversity and humanity, it is not surprising that in recent years the canopy crane is now being used for a drought experiment where through-fall rain is intercepted with plastic sheeting, hence reducing the amount of rain reaching the ground. This study, led by Professor Susan Laurance, is looking at tree and sapling responses to drought (Tng et al., 2018) and what may kill droughted trees. A new model examining how different guilds of insects respond to drought (Gely et al., 2019) is now being tested, with first results indicating that there are significantly more trees with wood borer damage in the droughted area compared to the control (Gely et al., 2021).

At the time of writing this manuscript the canopy crane is 22 years old, and while normally industrial cranes are installed and dismantled over short periods of time, this is a very long time for a crane to be standing in the tropics and experiencing sometimes more than 6000 millimetres of rain a year. So far it has withstood the elements extremely well and could well continue in situ for another 10 years. This description of the research that has been carried out using the crane mentions only a few of the more than 100 publications. Many aspects remain to be investigated, and the long-term data on the site flora and insects and the biophysical data will ensure that it is a critical site for a new range of studies in the future.

\section{Acknowledgements}

I thank the many JCU staff for their support and assistance in establishing and maintaining the canopy crane, including Professors Peter Arlett, Rhondda Jones and Norman Palmer, and other colleagues from The University of Queensland and Griffith University. I am particularly grateful to Fiona Barron who was critically important in driving and planning the project, and in particular getting it through various planning hoops. I thank Bill and Craig Jones of Morrow Cranes, staff at Hevilift, Dr Ken Chapman, Professor Ralph Slatyer and other CRC colleagues. This work was supported by grant DP130104092 from the ARC. 


\section{Literature Cited}

Basset, Y., Horlych, V., \& Wright, S. J. (2003). Studying Forest Canopies from Above: the International Canopy Crane Network. STRI \& UNEP.

Blüthgen, N., \& Fiedler, K. (2002). Interactions between weaver ants (Oecophylla smaragdina), homopterans, trees and lianas in an Australian rainforest canopy. Journal of Animal Ecology, 71, 793801. https://doi.org/10.1046/j.1365-2656.2002.00647.x

Blüthgen, N., \& Fiedler, K. (2004). Competition for composition: lessons from nectar-feeding ant communities. Ecology, 85, 1479-1485. https://doi.org/10.1890/03-0430

Blüthgen, N., Stork, N. E., \& Fiedler, K. (2004). Bottom-up control and co-occurrence in complex communities: honeydew and nectar determine a rainforest ant mosaic. Oikos, 106, 344-358. https:// doi.org/10.1111/j.0030-1299.2004.12687.x

Boulter, S. L., Kitching, R. L., \& Howlett, B. G. (2006). Family, visitors and the weather - patterns of flowering in tropical rainforests of northern Australia. Journal of Ecology, 94, 369-382. https://doi. org/10.1111/j.1365-2745.2005.01084.x

Boulter, S. L., Kitching, R. L., Howlett, B. G., \& Goodall, K. (2005). Any which way will do - the pollination biology of a northern Australian rainforest canopy tree (Syzygium sayeri; Myrtaceae). Botanical Journal of the Linnean Society, 149, 69-84. https://doi.org/10.1111/j.1095-8339.2005.00430.x

Buckton, G., Cheesman, A. W., Munksgaard, N. C., Wurster, C. M., Liddell, M. J., \& Cernusak, L. A. (2019). Functional traits of lianas in an Australian lowland rainforest align with post-disturbance rather than dry season advantage. Austral Ecology, 44(6), 983-994. https://doi.org/10.1111/aec.12764

Cox, C. J., Edwards, W., Campbell, M. J., Laurance, W. F., \& Laurance, S. G. (2019). Liana cover in the canopies of rainforest trees is not predicted by local ground-based measures. Austral Ecology, 44(5), 759-767. https://doi.org/10.1111/aec.12746

Erwin, T.L.(1982). Tropical forests: their richness in Coleoptera and other arthropod species. Coleopterists Bulletin, 36, 74-75.

Falster, D. S., \& Westoby, M. (2005). Alternative height strategies among 45 dicot rain forest species from tropical Queensland, Australia. Journal of Ecology, 93, 521-535. https://doi.org/10.1111/j.00220477.2005.00992.x

Fayle, T. M., Turner, E. C., Basset, Y., Ewers, R. M., Reynolds, G., \& Novotny, V. (2015). Whole-ecosystem experimental manipulations of tropical forests. Trends in Ecology \& Evolution, 30, 334-346. https:// doi.org/10.1016/j.tree.2015.03.010

Franks, P., \& Brodribb, T. J. (2005). Stomatal control and water transport in the xylem. In M. A.Zwieniecki, \& N. M. Holbrook (Eds.), Vascular transport in plants (pp. 69-89). Elsevier. https://doi.org/10.1016/ b978-012088457-5/50006-x

Franks, P. J. (2004). Stomatal control and hydraulic conductance, with special reference to tall trees. Tree Physiology, 24(8), 865-878. https://doi.org/10.1093/treephys/24.8.865

Freiberg, M., \& Turton, S. M. (2007). Importance of drought on the distribution of the birds nest fern, Asplenium nidus, in the canopy of a lowland tropical rainforest in north-eastern Australia. Austral Ecology, 32, 70-76. https://doi.org/10.1111/j.1442-9993.2007.01732.x

Gely, C., Laurance, S. G., \& Stork, N. E. (2019). How do herbivorous insects respond to drought stress in trees? Biological Reviews. https://doi.org/10.1111/brv.12571

Gely, C., Laurance, S. G., \& Stork, N. E. (2021). The effect of drought on wood-boring in trees and saplings in tropical rainforests. Forest Ecology and Management, 489, 119078. https://doi.org/10.1016/ j.foreco.2021.119078

Grimbacher, P. S., Nichols, C., Wardhaugh, C. W., \& Stork, N. E. (2014). Low host specificity of beetles associated with fruit falls in lowland tropical rainforest of north-east Australia. Austral Entomology, 53(1), 75-82. https://doi.org/10.1111/aen.12049

Laidlaw, M., Kitching, R. L., Goodall, K., Small, A., \& Stork, N. E. (2007). Temporal and spatial variation in an Australian tropical rainforest. Austral Ecology, 32(1), 10-20. https://doi.org/10.1111/ j.1442-9993.2007.01739.x 
Lucas, R. M., Held, A., Phinn, S., \& Saatchi, S. (2004). Tropical forests. In S. Ustin (Ed.), Manual of remote sensing (Vol. 4: Remote sensing for natural resource assessment) (pp. 239-315). American Society for Photogrammetry and Remote Sensing.

McCaig, T., Sam, L., Nakamura, A., \& Stork, N. E. (2020). Is insect vertical distribution in rainforests better explained by distance from the canopy top or distance from the ground? Biodiversity and Conservation, 29(3), 1081-1103. https://doi.org/10.1007/s10531-019-01927-0

Nakamura, A., Kitching, R. L., Cao, M., Creedy, T. J., Fayle, T. M., Freiberg, M., Hewitt, C., Itioka, T., Koh, L. P., \& Ma, K. (2017). Forests and their canopies: achievements and horizons in canopy science. Trends in Ecology \& Evolution, 32(6), 438-451. https://doi.org/10.1016/j.tree.2017.02.020

Nix, H. (1991). Biogeography: pattern and process. In H. Nix, \& M. Switzer (Eds.), Rainforest Animals. Atlas of vertebrates endemic to Australia's wet tropics (pp. 11-40). Australian National Parks and Wildlife Service.

Ozanne, C. M.P., Anhuf, D., Boulter, S. L., Keller, M., Kitching, R. L., Korner, C., Meinzer, F. C., Mitchell, A. W., Nakashizuka, T., Dias, P. L. S., Stork, N. E., Wright, S. J., \& Yoshimura, M. (2003). Biodiversity meets the atmosphere: A global view of forest canopies. Science, 301(5630), 183-186. https://doi. org/10.1126/Science. 1084507

Parker, G. G., Smith, A. P., \& Hogan, K. P. (1992). Access to the upper forest canopy with a large tower crane. BioScience, 42, 664-670. https://doi.org/10.2307/1312172

Stork, N. E. (1991). The composition of the arthropod fauna of Bornean lowland rain-forest trees. Journal of Tropical Ecology, 7, 161-180. https://doi.org/10.1017/S0266467400005319

Stork, N. E. (2018). How many species of insects and other terrestrial arthropods are there on Earth? Annual Review of Entomology, 63, 31-45. https://doi.org/10.1146/annurev-ento-020117-043348

Stork, N. E., \& Grimbacher, P. S. (2006). Beetle assemblages from an Australian tropical rainforest show that the canopy and the ground strata contribute equally to biodiversity. Proceedings of the Royal Society B: Biological Sciences, 273(1596), 1969-1975. https://doi.org/10.1098/rspb.2006.3521

Stork, N. E., Grimbacher, P. S., Storey, R., Oberprieler, R. G., Reid, C. A. M., \& Slipinski, A. (2008). What determines whether a species of insect is described? Evidence from a study of tropical forest beetles. Insect Conservation \& Diversity, 1, 114-119. https://doi.org/10.1111/j.1752-4598.2008.00016.x

Stork, N. E., Stone, M., \& Sam, L. (2016). Vertical stratification of beetles in tropical rainforests as sampled by light traps in North Queensland, Australia. Austral Ecology, 41(2), 168-178. https://doi. org/10.1111/aec.12286

Stork, N. E., Wright, S. J., \& Mulkey, S. S. (1997). Craning for a better view: The canopy crane network. Trends in Ecology \& Evolution, 12, 418-420. https://doi.org/10.1016/s0169-5347(97)01205-6

Tng, D. Y., Apgaua, D. M., Ishida, Y. F., Mencuccini, M., Lloyd, J., Laurance, W. F., \& Laurance, S. G. (2018). Rainforest trees respond to drought by modifying their hydraulic architecture. Ecology and Evolution, 8(24), 12479-12491. https://doi.org/10.1002/ece3.4601

Turton, S. M., \& Siegenthaler, D. T. (2004). Immediate impacts of a severe tropical cyclone on the microclimate of a tropical rainforest canopy in northeast Australia. Journal of Tropical Ecology, 20, 583-586. https://doi.org/10.1017/S0266467404001622

Wardhaugh, C. W., Edwards, W., \& Stork, N. E. (2013). Variation in beetle community structure across five microhabitats in Australian tropical rainforest trees. Insect Conservation and Diversity, 6(4), 463 472. https://doi.org/10.1111/icad.12001

Wardhaugh, C. W., Edwards, W., \& Stork, N. E. (2015). The specialization and structure of antagonistic and mutualistic networks of beetles on rainforest canopy trees. Biological Journal of the Linnean Society, 114(2), 287-295. https://doi.org/10.1111/bij.12430

Wardhaugh, C. W., Stork, N. E., \& Edwards, W. (2012). Feeding guild structure of beetles on Australian tropical rainforest trees reflects microhabitat resource availability. Journal of Animal Ecology, 81, 1086-1094. https://doi.org/10.1111/J.1365-2656.2012.01988.X 
Wardhaugh, C. W., Stork, N. E., \& Edwards, W. (2013). Specialization of rainforest canopy beetles to host trees and microhabitats: not all specialists are leaf-feeding herbivores. Biological Journal of the Linnean Society, 109(1), 215-228. https://doi.org/10.1111/Bij.12029

Wardhaugh, C. W., Stork, N. E., Edwards, W., \& Grimbacher, S. (2012). The overlooked biodiversity of flower-visiting invertebrates. PLOS One, 7(9), e45796. https://doi.org/10.1371/journal.pone.0045796

\section{Author Profile}

Nigel Stork is an Emeritus Professor at Griffith University. He previously worked for James Cook University, the University of Melbourne and Manchester University. While working at the Natural History Museum in London from 1980 to 1995, he developed a keen interest in the diversity of insects with field work in tropical forests of South America, Africa and South-East Asia. He became the CEO of the Rainforest Cooperative Research Centre in 1995, based in Cairns, where he managed a broad portfolio of industry-led research on all aspects of the Wet Tropics rainforest and its people. He is best known for his research on tropical forest canopies and answering the question of how many species of insects there are on Earth. 